\title{
PENGAPLIKASIAN METODE GOAL PROGRAMMING PADA PERENCANAAN PRODUKSI STAINLESS STEEL (Studi kasus : PT. Jindal Stainless Indonesia)
}

\author{
Ndaru Singgih Pratama ${ }^{1)}$, Said Salim Dahda ${ }^{2)}$, Elly Ismiyah ${ }^{3)}$ \\ ${ }^{1}$ Mahasiswa Teknik Industri, Fakultas Teknik, Universitas Muhammadiyah Gresik \\ ${ }^{2,3}$ Dosen Teknik Industri, Fakultas Teknik, Universitas Muhammadiyah Gresik \\ Jl. Sumatera No. 101 GKB - Gresik 61121 \\ e-mail : ndarusinggih@gmail.com
}

\begin{abstract}
ABSTRAK
PT. Jindal Stainless Indonesia (JSI) merupakan pabrik stainless pertama dan terbesar di Indonesia dari tahun 1996 hingga sekarang dan mampu memproduksi hingga 8.000 MT/bln. PT. Jindal Stainless Indonesia memproduksi 3 macam material stainless berdasarkan kandungan nikel yang berbeda, yakni series 200, series 300, dan series 400. Perencanaan produksi merupakan salah satu hal yang penting dalam perusahaan manufaktur yang berhubungan dengan penentuan volume, ketepatan waktu penyelesaian, utilisasi kapasitas, dan pemerataan beban. Kebutuhan material stainless dari tahun ke tahun semakin meningkat dan banyaknya permintaan konsumen menjadikan perusahaan terus menambah jumlah produksi agar dapat memenuhi permintaan konsumen. Oleh karena itu, penelitian ini bertujuan untuk meramalkan permintaan dan mengaplikasikan model goal progamming untuk membuat perencanaan produksi yang dapat memaksimalkan jumlah produksi perusahaan sehingga memperoleh hasil yang optimal. Dari hasil penelitian memperoleh beberapa solusi yang optimal yaitu hasil peramalan minitab 17.0 dengan menggunakan metode Time Series (Double Exponential Smoothing) dan didapatkan hasil peramalan sebagai berikut, produk series 200 periode July 2019 - Desember 2019 (2.109, 2.113, 2.116, 2.119, 2.111, 2.125), produk series 300 periode July 2019 - Desember 2019 (2.187, 2.192, 2.196, 2.201, 2.205, 2.210), dan series 400 periode July 2019 - Desember 2019 (3.253, 3.273, 3.283, 3.293, 3.303, 3.312). Sedangkan hasil perencanaan produksi pada periode July 2019 - Desember 2019 bisa terpenuhi dengan bantuan software LINGO 17.0, sehingga didapatkan hasil produksi yang optimal.
\end{abstract}

Kata Kunci : Peramalan, Time Series, Goal Programming, LINGO 17.0.

\section{PENDAHULUAN}

Perkembangan industri semakin pesat dari tahun ke tahun, perkembangan ini berasal dari banyaknya barang atau hasil produksi yang semakin diminati di pasaran sehingga para produsen semakin meningkatkan kemampuan untuk memenuhi permintaan konsumen. Perencanaan produksi merupakan salah satu hal yang penting dalam perusahaan manufaktur yang berhubungan dengan penentuan volume, ketepatan waktu penyelesaian, utilisasi kapasitas, dan pemerataan beban. Perencanaan produksi umumnya dilakukan dengan taksiran permintaan berdasarkan pengalaman masa lalu (Devani, 2014). Perencanaan produksi bertujuan memberikan keputusan yang optimum berdasarkan sumber daya yang dimiliki perusahaan dalam memenuhi permintaan, seperti kapasitas mesin, tenaga kerja, teknologi, dan lain-lain (Nasution, 2008).

PT. Jindal Stainless Indonesia (JSI) merupakan pabrik stainless pertama dan terbesar di Indonesia dari tahun 1996 hingga sekarang dan mampu memproduksi hingga $8.000 \mathrm{MT} / \mathrm{bln}$. PT. Jindal Stainless Indonesia memproduksi 3 macam material stainless berdasarkan kandungan nikel yang berbeda, yakni series 200, series 300, dan series 400. PT. Jindal Stainless Indonesia merupakan salah satu industri yang diminati dalam industri manufaktur stainless karena material stainless memiliki sifat ketahanan terhadap korosi. Sifat tahan korosi didapat dari lapisan oksida (terutama chrom) yang sangat stabil menempel pada permukaan dan melindungi baja terhadap lingkungan yang korosif. Kebutuhan material stainless dari tahun ke tahun semakin meningkat (tabel 1, tabel 2, dan tabel 3) dan banyaknya permintaan konsumen menjadikan perusahaan terus menambah jumlah produksi agar dapat memenuhi permintaan konsumen. Permintaan konsumen dapat terealisasi seluruhnya di dalam rencana produksi jika didukung oleh kapasitas produksi yang sesuai dengan kebutuhan produksi (Carlinawati, 2018)

Berikut ini adalah data rencana produksi, permintaan pelanggan dan realisasi produksi produk stainless tahun 2017 dan 2018.

Tabel 1 Data Rencana Produksi, Permintaan

Pelanggan dan Realisasi Produksi Produk

Stainless Series 200.

\begin{tabular}{|c|c|}
\hline Tahun & SERIES 200 \\
Metrik Ton (MT)
\end{tabular}




\begin{tabular}{|c|c|c|c|}
\cline { 2 - 4 } & $\begin{array}{c}\text { Rencana } \\
\text { Produksi }\end{array}$ & $\begin{array}{c}\text { Permintaan } \\
\text { Pelanggan }\end{array}$ & $\begin{array}{c}\text { Realisasi } \\
\text { Produksi }\end{array}$ \\
\hline $\mathbf{2 0 1 7}$ & 23.077 & 24.478 & 23.466 \\
\hline $\mathbf{2 0 1 8}$ & 21.187 & 25.005 & 23.913 \\
\hline Jumlah & 44.264 & 49.484 & 47.379 \\
\hline
\end{tabular}

Sumber : Departemen PPIC PT. Jindal

Stainless Indonesia

Tabel 2 Data Rencana Produksi, Permintaan

Pelanggan dan Realisasi Produksi Produk

Stainless Series 300.

\begin{tabular}{|c|c|c|c|}
\hline \multirow{2}{*}{ Tahun } & \multicolumn{3}{|c|}{$\begin{array}{c}\text { SERIES 300 } \\
\text { Metrik Ton (MT) }\end{array}$} \\
\cline { 2 - 4 } & $\begin{array}{c}\text { Rencana } \\
\text { Produksi }\end{array}$ & $\begin{array}{c}\text { Permintaan } \\
\text { Pelanggan }\end{array}$ & $\begin{array}{c}\text { Realisasi } \\
\text { Produksi }\end{array}$ \\
\hline $\mathbf{2 0 1 7}$ & 28.110 & 25.132 & 31.966 \\
\hline $\mathbf{2 0 1 8}$ & 29.298 & 25.608 & 28.138 \\
\hline Jumlah & 57.408 & 50.740 & 60.104 \\
\hline
\end{tabular}

Sumber : Departemen PPIC PT. Jindal

Stainless Indonesia

Tabel 3 Data Rencana Produksi, Permintaan

Pelanggan dan Realisasi Produksi Produk

Stainless Series 400.

\begin{tabular}{|c|c|c|c|}
\hline \multirow{2}{*}{ Tahun } & \multicolumn{3}{|c|}{$\begin{array}{c}\text { SERIES 400 } \\
\text { Metrik Ton (MT) }\end{array}$} \\
\cline { 2 - 4 } & $\begin{array}{c}\text { Rencana } \\
\text { Produksi }\end{array}$ & $\begin{array}{c}\text { Permintaan } \\
\text { Pelanggan }\end{array}$ & $\begin{array}{c}\text { Realisasi } \\
\text { Produksi }\end{array}$ \\
\hline $\mathbf{2 0 1 7}$ & 33.771 & 36.706 & 31.809 \\
\hline $\mathbf{2 0 1 8}$ & 32.844 & 37.331 & 34.041 \\
\hline Jumlah & 66.615 & 74.036 & 65.850 \\
\hline
\end{tabular}

Sumber : Departemen PPIC PT. Jindal

Stainless Indonesia

Berikut adalah data kapasitas produksi PT. Jindal Stainless Indonesia :

Tabel 4 Data Kapasitas Produksi PT. Jindal

Stainless Indonesia

\begin{tabular}{|c|c|c|}
\hline No. & Mesin & $\begin{array}{c}\text { Kapasitas Produksi } \\
\text { (MT/Hari) }\end{array}$ \\
\hline $\mathbf{1}$ & Mesin A & 140 \\
\hline $\mathbf{2}$ & Mesin B & 140 \\
\hline
\end{tabular}

Sumber : Departemen PPIC PT. Jindal

Stainless Indonesia

Dan berikut gambar 1 menampilkan rencana, realisasi produksi dan permintaan pelanggan yang mengalami fluktuasi permintaan yang tidak stabil pada periode Januari 2017 - Desember 2018.

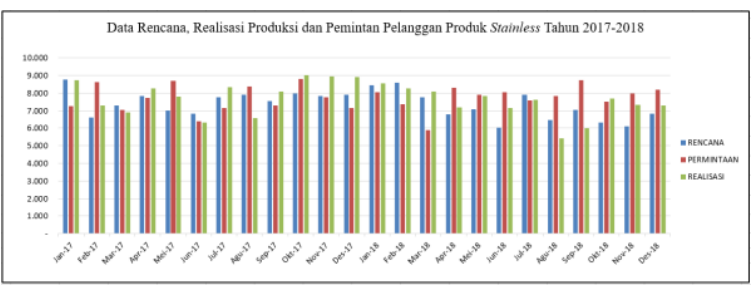

Gambar 1 Grafik Rencana, Realisasi Produksi dan Permintaan Pelanggan Produk Stainless Periode 2017 - 2018.

Selama periode 2017 dan 2018, pada bulan tertentu PT. Jindal Stainless mengalami fluktuasi dalam rencana, realisasi produksi dan permintaan pelanggan yang menyebabkan mengalami overstcok dan understok. Overstock terjadi ketika kelebihan produksi atau realisasi produksi lebih besar dibandingkan dengan permintaan pelanggan dan akan mengalami understock ketika perusahaan tidak dapat memenuhi permintaan pelanggan karena pada kenyataannya konsumen sering menambah pesanan jumlah produk jadi permintaan bulanan tidak dapat dipastikan. Perencanaan produksi PT. Jindal Stainless selama ini hanya menggunakan perkiraan data masalalu. Dalam perencanaan produksi PT. Jindal Stainless terdapat beberapa kendala yang dialami oleh perusahaan antara lain, jumlah permintaan yang berfluktuatif dan juga perusahaan belum mampu memanfaatkan kapasitas mesin yang ada.

Permintaan pelanggan mengalami fluktuasi seperti gambar 1 sehingga permintaan bulanan tidak dapat dipastikan. Realisasi produksi PT. Jindal Stainless mengalami ketidakmampuan untuk memenuhi permintaan pelanggannya yang mengakibatkan perusahaan tidak dapat mengambil kesempatan untuk mendapatkan kepercayaan dari pelanggan.

Jumlah Realisasi produksi didasarkan atas perencanaan produksi dan kapasitas produksi PT. Jindal Stainless serta mengakomodasi kekurangan pesanan sebelumnya yang tidak dapat dipenuhi dengan realisasi sebelumnya. Realisasi produksi PT. Jindal Stainless masih kurang optimal untuk memenuhi rencana produksi.

Pada penelitian ini menggunakan metode time series agar bisa menganalisis permintaan selanjutnya dan perencaanaan produksi yang optimal menggunakan metode goal programming dalam pengolahan data pembuatan model matematisnya dengan dibantu software LINGO untuk mengantisipasi 
kekurangan dan kelebihan produksi yakni pada periode July 2019 - Desember 2019.

\section{METODOLOGI PENELITIAN}

Metodologi penelitian merupakan gambaran penelitian secara keseluruhan sehingga dapat diketahui proses, metode, dan hasil yang diperoleh dari penelitian ini. Obyek dalam penelitian ini adalah Perencanaan Produksi Pada PT. Jindal Stainless Indonesia.

Penelitian ini dimulai dengan survei pendahuluan untuk mengidentifikasi permasalahan yang terjadi kemudian dilakukan perumusan masalah dan penentuan tujuan penelitian setelah itu dilakukan studi literatur dan studi lapangan untuk mengetahui dengan jelas permasalahan yang terjadi dan langkah penyelasianya. Pada penelitian ini penyelesaian permasalahan menggunakan metode peramlan (time series) dan goal programming.

\section{HASIL DAN PEMBAHASAN}

Pada tahap pengumpulan data pada penelitian ini didapatkan data berupa informasi mengenai perencanaan produksi, permintaan pelanggan dan kapasitas produksi yang digunakan di PT. Jindal Stainless Indonesia. Data yang terkumpul diperoleh dari pengamatan secara langsung, wawancara dengan pihak internal perusahaan, dan dokumen-dokumen yang dimiliki oleh perusahaan.

Pada penelitian ini data diolah dengan bantuan software Minitab 17.0 untuk melakukan peramalan permintaan produk, sedangkan pada penyelesaian model goal programming menggunakan bantuan software LINGO 17.0.

\section{Analisis Hasil Peramalan Permintaan}

Dari hasil pengolahan, dihasilkan peramalan permintaan produk stainless di PT. Jindal Stainless Indonesia sebagai berikut :

\section{A. Series 200}

Pada peramalan permintaan produk Series 200 menggunakan software Minitab 17. Data yang digunakan untuk peramalan adalah data permintaan produk Series 200 pada periode Januari 2017 - Juni 2019. Data tersebut akan digunakan untuk meramalkan target produksi pada periode July - Desember 2019. Pola data yang dihasilkan di software Minitab 17 menjelaskan bahwa data yang digunakan mengandung unsur fluktuasi sehingga metode yang digunakan adalah metode Time Series yaitu double exponential smoothing. Maka diperoleh hasil ramalan permintaan produk pada periode July 2019 - Desember 2019 sebagai berikut :

Tabel 5 Hasil Peramalan Produk Series 200

\begin{tabular}{|c|c|}
\hline Periode & Hasil Peramalan (MT) \\
\hline July & 2.109 \\
\hline Agustus & 2.113 \\
\hline September & 2.116 \\
\hline Oktober & 2.119 \\
\hline November & 2.111 \\
\hline Desember & 2.125 \\
\hline
\end{tabular}

B. Series 300

Pada peramalan permintaan produk Series 300 menggunakan software Minitab 17. Data yang digunakan untuk peramalan adalah data permintaan produk Series 300 pada periode Januari 2017 - Juni 2019. Data tersebut akan digunakan untuk meramalkan target produksi pada periode July - Desember 2019. Pola data yang dihasilkan di software Minitab 17 menjelaskan bahwa data yang digunakan mengandung unsur fluktuasi sehingga metode yang digunakan adalah metode Time Series yaitu double exponential smoothing. Maka diperoleh hasil ramalan permintaan produk pada periode July 2019 - Desember 2019 sebagai berikut :

Tabel 6 Hasil Peramalan Produk Series 300

\begin{tabular}{|c|c|}
\hline Periode & Hasil Peramalan (MT) \\
\hline July & 2.187 \\
\hline Agustus & 2.192 \\
\hline September & 2.196 \\
\hline Oktober & 2.201 \\
\hline November & 2.205 \\
\hline Desember & 2.210 \\
\hline
\end{tabular}

C. Series 400

Pada peramalan permintaan produk Series 400 menggunakan software Minitab 17. Data yang digunakan untuk peramalan adalah data permintaan produk Series 400 pada periode Januari 2017 - Juni 2019. Data tersebut akan digunakan untuk meramalkan target produksi pada periode July - Desember 2019. Pola data yang dihasilkan di software Minitab 17 menjelaskan bahwa data yang digunakan mengandung unsur fluktuasi sehingga metode yang digunakan adalah metode Time Series yaitu double exponential smoothing. Maka diperoleh hasil ramalan permintaan produk pada periode July 2019 - Desember 2019 sebagai berikut :

Tabel 7 Hasil Peramalan Produk Series 400 


\begin{tabular}{|c|c|}
\hline Periode & Hasil Peramalan (MT) \\
\hline July & 3.263 \\
\hline Agustus & 3.273 \\
\hline September & 3.283 \\
\hline Oktober & 3.293 \\
\hline November & 3.303 \\
\hline Desember & 3.312 \\
\hline
\end{tabular}

\section{Analisis Hasil Model Goal Programming}

Fungsi tujuan dari penelitian ini berdasarkan model goal programming adalah untuk memaksimalkan permintaan produk dan memaksimalkan kapasitas produksi perusahaan, agar perencanaan produksi bisa optimal. Karena perusahaan ingin memaksimalkan kendala-kendala yang ada.

Untuk pengembangan model goal programming yaitu dengan kendala permintaan dan kapasitas produksi yang direncanakan oleh perusahaan adalah sebagai berikut :

* Pada periode pertama, July 2019 DA01, DA07, DA013, DB019, DB025.

* Pada periode kedua, Agustus 2019 DA02, DA08, DA014, DB020, DB026.

* Pada periode ketiga, September 2019 DA03, DA09, DA015, DB021, DB027.

* Pada periode keempat, Oktober 2019 DA04, DA010, DA016, DB022, DB028.

* Pada periode kelima, November 2019 DA05, DA011, DA017, DB023, DB029.

* Pada periode keenam, Desember 2019 DA06, DA012, DA018, DB024, DB030.

\section{Analisis Hasil LINGO 17.0}

Dari hasil pengolahan data pada bab sebelumnya dihasilkan masing-masing jumlah produk, sebagai berikut :

A. Series 200

* Pada periode pertama bulan July 2019 yang diproduksi mesin A (X111) sebesar 1593 MT dan mesin B (X121) sebesar 516 MT untuk memenuhi permintaan sebesar 2109 MT. Jumlah ini sesuai dengan kendala permintaan di periode ini, yaitu X111 + X121+ DA01 - DB01 = 2109 .

* Pada periode kedua bulan Agustus 2019 yang diproduksi mesin A (X112) sebesar 1606 MT dan mesin B (X122) sebesar 507 MT untuk memenuhi permintaan sebesar 2113 MT. Jumlah ini sesuai dengan kendala permintaan di periode ini, yaitu X112+X122+ DA02 - DB02 $=2113$.
* Pada periode ketiga bulan September 2019 yang diproduksi mesin A (X113) sebesar 1899 MT dan mesin B (X123) sebesar 217 MT untuk memenuhi permintaan sebesar 2116 MT. Jumlah ini sesuai dengan kendala permintaan di periode ini, yaitu X113 + X123 + DA03 - DB03 = 2116 .

* Pada periode keempat bulan Oktober 2019 yang diproduksi mesin A (X114) sebesar 1632 MT dan mesin B (X124) sebesar 487 MT untuk memenuhi permintaan sebesar 2119 MT. Jumlah ini sesuai dengan kendala permintaan di periode ini, yaitu X114 + X124+ DA04 - DB04 = 2119 .

* Pada periode kelima bulan November 2019 yang diproduksi mesin A (X115) sebesar 1774 MT dan mesin B (X125) sebesar 337 MT untuk memenuhi permintaan sebesar 2111 MT. Jumlah ini sesuai dengan kendala permintaan di periode ini, yaitu X115 + X125 + DA05 - DB05 = 2111 .

* Pada periode keenam bulan Desember 2019 yang diproduksi mesin A (X116) sebesar 1797 MT dan mesin B (X126) sebesar 328 MT untuk memenuhi permintaan sebesar 2125 MT. Jumlah ini sesuai dengan kendala permintaan di periode ini, yaitu X116 + X126+ DA06 - DB06 $=2125$.

B. Series 300

* Pada periode pertama bulan July 2019 yang diproduksi mesin A (X211) sebesar 2187 MT dan mesin B (X221) sebesar 0 MT untuk memenuhi permintaan sebesar 2187 MT. Jumlah ini sesuai dengan kendala permintaan di periode ini, yaitu X211 + X221 + DA07 - DB07 $=2187$.

* Pada periode kedua bulan Agustus 2019 yang diproduksi mesin A (X212) sebesar 2192 MT dan mesin B (X222) sebesar 0 MT untuk memenuhi permintaan sebesar 2192 MT. Jumlah ini sesuai dengan kendala permintaan di periode ini, yaitu X212 + X222+ DA08 - DB08 = 2192 .

* Pada periode ketiga bulan September 2019 yang diproduksi mesin A (X213) sebesar 2196 MT dan mesin B (X223) sebesar 0 MT untuk memenuhi permintaan sebesar 2196 MT. Jumlah 
ini sesuai dengan kendala permintaan di periode ini, yaitu X213 + X223 + DA09 - DB09 = 2196.

* Pada periode keempat bulan Oktober 2019 yang diproduksi mesin A (X214) sebesar 2201 MT dan mesin B (X224) sebesar 0 MT untuk memenuhi permintaan sebesar 233 MT. Jumlah ini sesuai dengan kendala permintaan di periode ini, yaitu X214 + X224+ DA010 - DB010 = 2201 .

* Pada periode kelima bulan November 2019 yang diproduksi mesin A (X215) sebesar 2205 MT dan mesin B (X225) sebesar 0 MT untuk memenuhi permintaan sebesar 233 MT. Jumlah ini sesuai dengan kendala permintaan di periode ini, yaitu X215 + X225+ DA011 - DB011 = 2205 .

* Pada periode keenam bulan Desember 2019 yang diproduksi mesin A (X216) sebesar 2210 MT dan mesin B (X226) sebesar 0 MT untuk memenuhi permintaan sebesar 233 MT. Jumlah ini sesuai dengan kendala permintaan di periode ini, yaitu X216 + X226 + DA012 - DB012 $=2210$.

C. Series 400

* Pada periode pertama bulan July 2019 yang diproduksi mesin A (X311) sebesar 0 MT dan mesin B (X321) sebesar 3263 MT untuk memenuhi permintaan sebesar 233 MT. Jumlah ini sesuai dengan kendala permintaan di periode ini, yaitu X311 $+\mathrm{X} 321+$ DA013 - DB013 = 3263 .

* Pada periode kedua bulan Agustus 2019 yang diproduksi mesin A (X312) sebesar 0 MT dan mesin B (X322) sebesar 3273 MT untuk memenuhi permintaan sebesar 3273 MT. Jumlah ini sesuai dengan kendala permintaan di periode ini, yaitu X312+X322+ DA014 - DB014 = 3273

* Pada periode ketiga bulan September 2019 yang diproduksi mesin A (X313) sebesar 0 MT dan mesin B (X323) sebesar 3283 MT untuk memenuhi permintaan sebesar 3283 MT. Jumlah ini sesuai dengan kendala permintaan di periode ini, yaitu $\mathrm{X} 313+\mathrm{X} 323+$ DA015 - DB015 = 3283 .

* Pada periode keempat bulan Oktober 2019 yang diproduksi mesin A (X314) sebesar 0 MT dan mesin B (X324) sebesar 3293 MT untuk memenuhi permintaan sebesar 3293 MT. Jumlah ini sesuai dengan kendala permintaan di periode ini, yaitu X314 + X324+ DA016 - DB016 = 3293 .

* Pada periode kelima bulan November 2019 yang diproduksi mesin A (X315) sebesar 0 MT dan mesin B (X325) sebesar 3303 MT untuk memenuhi permintaan sebesar 3303 MT. Jumlah ini sesuai dengan kendala permintaan di periode ini, yaitu X315 + X325 + DA017 - DB017 = 3303 .

* Pada periode keenam bulan Desember 2019 yang diproduksi mesin A (X316) sebesar 0 MT dan mesin B (X326) sebesar 3312 MT untuk memenuhi permintaan sebesar 3312 MT. Jumlah ini sesuai dengan kendala permintaan di periode ini, yaitu X316 + X326 + DA018 - DB018 $=3312$.

Tabel 8 Hasil Pembagian Produksi Mesin A dan B dengan Menggunakan LINGO 17.0

\begin{tabular}{|c|c|c|c|c|}
\hline Periode & Produk & Mesin A & Mesin B & Total \\
\hline \multirow{3}{*}{ July } & Series 200 & 1.593 & 516 & 2.109 \\
\hline & Series 300 & 2.187 & - & 2.187 \\
\hline & Series 400 & - & 3.264 & 3.264 \\
\hline \multicolumn{2}{|c|}{ Jumlah Total } & 3.780 & 3.780 & 7.560 \\
\hline \multirow{3}{*}{ Agustus } & Series 200 & 1.606 & 507 & 2.113 \\
\hline & Series $\mathbf{3 0 0}$ & 2.192 & - & 2.192 \\
\hline & Series 400 & - & 3.273 & 3.273 \\
\hline \multicolumn{2}{|c|}{ Jumlah Total } & 3.798 & 3.780 & 7.578 \\
\hline \multirow{3}{*}{ September } & Series 200 & 1.899 & 217 & 2.166 \\
\hline & Series 300 & 2.196 & - & 2.196 \\
\hline & Series 400 & - & 3.283 & 3.283 \\
\hline \multicolumn{2}{|c|}{ Jumlah Total } & 4.095 & 3.500 & 7.645 \\
\hline \multirow{3}{*}{ Oktober } & Series 200 & 1.632 & 487 & 2.119 \\
\hline & Series 300 & 2.201 & - & 2.201 \\
\hline & Series 400 & - & 3.293 & 3.293 \\
\hline \multicolumn{2}{|c|}{ Jumlah Total } & 3.833 & 3.780 & 7.613 \\
\hline \multirow{3}{*}{ November } & Series 200 & 1.774 & 337 & 2.111 \\
\hline & Series 300 & 2.205 & - & 2.205 \\
\hline & Series 400 & - & 3.303 & 3.303 \\
\hline \multicolumn{2}{|c|}{ Jumlah Total } & 3.979 & 3.640 & 7.619 \\
\hline \multirow{3}{*}{ Desember } & Series 200 & 1.797 & 328 & 2.125 \\
\hline & Series 300 & 2.210 & - & 2.210 \\
\hline & Series 400 & - & 3.312 & 3.312 \\
\hline \multicolumn{2}{|c|}{ Jumlah Total } & 4.007 & 3.640 & 7.647 \\
\hline
\end{tabular}

\section{KESIMPULAN DAN SARAN}

\section{A. Kesimpulan}

Dari penelitian yang telah dilakukan, didapatkan kesimpulan sebagai berikut : 
1. Hasil peramalan jumlah permintaan produk periode July 2019-Desember 2019.

a) Series 200

Hasil peramalan permintaan produk Series 200 menggunakan metode Time Series yaitu double exponential smoothing pada software Minitab 17.0. Maka diperoleh hasil ramalan permintaan produk (dalam MT) pada periode July 2019 Desember 2019 adalah 2.109, 2.113, 2.116, 2.119, 2.111, 2.125.

b) Series 300

Hasil peramalan permintaan produk Series 300 menggunakan metode Time Series yaitu double exponential smoothing pada software Minitab 17.0. Maka diperoleh hasil ramalan permintaan produk (dalam MT) pada periode July 2019 Desember 2019 adalah 2.187, 2.192, 2.196, 2.201, 2.205, 2.210 .

c) Series 400

Hasil peramalan permintaan produk Series 400 menggunakan metode Time Series yaitu double exponential smoothing pada software Minitab 17.0. Maka diperoleh hasil ramalan permintaan produk (dalam MT) pada periode July 2019 Desember 2019 adalah 3.263, 3.273, 3.283, 3.293, 3.303, 3.312.

2. Model Goal Programming untuk perencanaan produksi PT. Jindal Stainless

$\operatorname{Min} \mathrm{Z}=\mathrm{DA} 01+\mathrm{DA} 02+\ldots \quad+$ DB29 + DB30;

$$
\begin{aligned}
& \sum X_{i j k}+X_{i j k}+D A_{k}-D B_{k}=D_{i j k} \\
& \sum \frac{X_{i j k}}{K_{j}}+\frac{X_{i j k}}{K_{j}}+D A_{k}-D B_{k}=T_{k}
\end{aligned}
$$

Dimana :

$X_{i j k}=$ Jumlah produk $i$ yang melewati fasilitas $j$ pada periode $k$

$D_{i j k}=$ Peramalan permintaan produk $i$ yang melewati fasilitas $j$ pada periode $k$

$K_{J} \quad=$ Kapasitas mesin $j$ (MT/Hari)

$T_{k} \quad=$ Kapasitas waktu pada periode $k$

$D A_{k}=$ Deviasi negatif pada pembatas ke $k$

$D B_{k} \quad=$ Deviasi positif pada pembatas ke $k$

3. Hasil perencanaan produksi pada periode July 2019 - Desember 2019 berdasarkan model Goal Programming dengan bantuan software Lingo 17.0 : a) Pada bulan July 2019, Mesin A dan B dapat memenuhi permintaan dari hasil peramalan permintaan.

b) Pada bulan Agustus 2019, Mesin A dan B dapat memenuhi permintaan dari hasil peramalan permintaan.

c) Pada bulan September 2019, Mesin A dan $\mathrm{B}$ dapat memenuhi permintaan dari hasil peramalan permintaan.

d) Pada bulan Oktober 2019, Mesin A dan B dapat memenuhi permintaan dari hasil peramalan permintaan.

e) Pada bulan November 2019, Mesin A dan $\mathrm{B}$ dapat memenuhi permintaan dari hasil peramalan permintaan.

f) Pada bulan Desember 2019, Mesin A dan $B$ dapat memenuhi permintaan dari hasil peramalan permintaan.

\section{DAFTAR PUSTAKA}

Anis, M., dan Utami, S. N. (2007). Optimasi Perencanaan Produksi Dengan Metode Goal Programming. Jurnal Ilmiah Teknik Industri, 5, 133-143.

Carlinawati, Nika. (2018). Perencanaan Kapasitas Produksi Tissue Botol Dengan Metode Capacity Requirements Planning di PT Cool Clean Malang. Skripsi. Program Studi Teknik Industri, Universitas Brawijaya, Malang.

Devani, Vera. (2014). Optimasi Perencanaan Produksi Dengan Menggunakan Metode Goal Progamming. Jurnal Sains dan Teknologi Industri, 11, 84-91.

Fahmi, G. D. (2018). Penerapan Model Goal Programming dan Integer Programming Untuk menentukan Jumlah Yang Optimal. Skripsi. Program Studi Teknik Industri, Universitas Muhammadiyah Gresik, Gresik.

Fauziyah. (2016). Penerapan Metode Goal Programming untuk Mengoptimalkan beberapa tujuan pada Perusahaan dengan Kendala Jam Kerja, Permintaan dan Bahan Baku. Jurnal Matematika Mantik 2 (1): 52-59.

Ginting, Rosnani. (2007). Sistem Produksi. Yogyakarta: Graha Ilmu.

Hardiyanti, Ismi., Setyanto, Nasir Widha., Rahman, Arif. (2015). Penjadwalan Produksi Menggunakan Metode Linear Programming Untuk Minimasi Biaya Produksi (Studi Kasus : Ud. Burno Sari, Lumajang). Jurnal Universitas 
Brawijaya, Universitas Brawijaya, Malang.

Harjiyanto, T. (2014). Aplikasi Model Goal Programming Untuk Optimasi Produk Aksessoris (Studi Kasus : PT. Kosama Jaya Banguntapan Bantul). Skripsi. Universitas Negeri Yogyakarta, Yogyakarta.

Hendradi, C. T. (2006). Statistik Six Sigma Dengan Minitab. Yogyakarta: Andi Offset.

Kartikasari, Viennetta. (2017). Perencanaan Produksi Menggunakan Metode Goal Programming Di PT. X. Skripsi. Program Studi Teknik Industri, Universitas Katolik Widya Mandala Surabaya, Surabaya.

Leliana R, Yohanes ARL \& Tohap M. (2013). Optimasi Pendistribusian Raskin dengan Menggunakan Goal Programming. Jurnal MIPA UNSRAT ONLINE 2 (1): 12-16.

Marpaung, J. (2009). Perencanaan Produksi Yang Optimal Dengan Pendekatan Goal Programming Di PT. Gold Coin Indonesia. Skripsi. Universitas Sumatera Utara, Medan.

Mulyono, S. (2017). Riset Operasi. Edisi 2. Jakarta: Mitra Wacana Media.

Nasution, A. H., \& Prasetyawan, Y. (2008). Perencanaan dan Pengendalian Produksi. Yogyakarta: Graha Ilmu.

Puryani, \& Ristono, A. (2012). Penelitian Operasional. Yogyakarta: Graha Ilmu.

Sari, Gita. (2018). Optimasi Perencanaan Produksi Kopi Bubuk Dengan Metode Goal Programming Berbasis QM For Windows (Studi Kasus : Industri Rumahan Kopi Bubuk Sr Asli Lampung di Waydadi Kecamatan Sukarame). Skripsi. Fakultas Tarbiyah dan Keguruan, Universitas Islam Negeri (UIN) Raden Intan Lampung. Lampung

Siswanto. (2007). Operation Research Jilid 1. Jakarta: Erlangga.

Sofyan, D. K. (2013). Perencanaan \& Pengendalian Produksi. Yogyakarta: Graha Ilmu.

Stevenson, W.J. dan Choung, S.C. (2014). Management Operasi Perspektif Asia. Edisi 9. Jakarta: Salemba Empat.

Taha, Hamdi A. (2003). Operations Research An Introduction. Edisi 7. New Jersey: Pearson Education, Inc.
Tersine, Richard J. (1994). Principles of Inventory And Materials Management. Edisi 4. United States of America: Prentice-Hall, Inc. 